\title{
Evaluation of Penman-Monteith model applied to a maize field in the arid area of northwest China
}

\author{
W.-Z. Zhao ${ }^{1,2}$, X.-B. Ji ${ }^{1,2}$, E.-S. Kang ${ }^{1}$, Z.-H. Zhang ${ }^{1,2}$, and B.-W. Jin ${ }^{1,2}$ \\ ${ }^{1}$ Heihe Key Laboratory of Ecohydrology and Integrated River Basin Science, Cold and Arid Regions Environmental and \\ Engineering Research Institute, Chinese Academy of Sciences, Lanzhou, 730000, China \\ ${ }^{2}$ Linze Inland River Basin Comprehensive Research Station, Chinese Ecosystem Research Network, Lanzhou, 730000, China
}

Received: 18 December 2009 - Published in Hydrol. Earth Syst. Sci. Discuss.: 21 January 2010

Revised: 28 April 2010 - Accepted: 1 July 2010 - Published: 29 July 2010

\begin{abstract}
The Penman-Monteith (P-M) model has been applied to estimate evapotranspiration in terrestrial ecosystem throughout the world. As shown in many studies, bulk canopy resistance is an especially important factor in the application of the P-M model. In this study, the authors used the Noilhan and Planton (N-P) approach and the Jacobs and De Bruin (J-D) approach to express the bulk canopy resistance. The P-M model was applied to a maize field using the two approaches in an arid area of northwest China and evaluated on the basis of measured half-hourly values from the eddy covariance system. The results indicate that the N-P approach slightly underestimates the bulk canopy resistance, while the J-D approach overestimates it. Over the entire maize growing season, the N-P approach yielded a more consistent estimate of bulk canopy resistance than did the J-D approach. Correspondingly, the P-M model with J-D bulk canopy resistance slightly underestimated the latent heat flux throughout the maize growing season, but overestimated the latent heat flux during the dry season as compared to the N-P approach results. The good fit between the simulated latent heat flux estimated by the P-M model using the N-P approach and the data measured at half-hour time steps demonstrates that the application of this approach is reasonable in relatively homogenous maize fields that are not drought-stressed. Further research to improve the performance of P-M model to simulate evapotranspiration in the cropped fields is discussed.
\end{abstract}

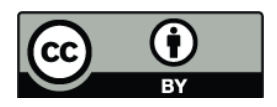

Correspondence to: W. Zhao (zhaowzh@lzb.ac.cn)

\section{Introduction}

Evapotranspiration (ET) is a principal component of the hydrological cycle in terrestrial ecosystems, affected by both biophysical and environmental processes at the interface between soil, vegetation, and atmosphere (Monteith and Unsworth, 1990; Sellers, et al., 1996; Baldocchi and Meyers, 1998). It serves as a regulator of the key ecological processes by linking stomatal activity, carbon exchange, and water use (Vörösmarty et al., 1998), and by linking energy balance and water balance of natural and agricultural ecosystems (Molina et al., 2006).

Quantification of water loss by ET is of primary importance for monitoring, surveying and managing water resources in the various spatial scales of a farm, a catchment, and a region (Lecina et al., 2003; Molina et al., 2006). For arid regions, ET estimation is extremely important to assess water resources. The arid inland area of northwest China consists of various, relatively independent, inland river basins. Water resources in an inland basin originate from the mountains and control the vegetation distribution in the basin (Ji et al., 2006; Kang et al., 2007). The extremely limited water resources are mostly utilized by the artificial oases in the middle-stream plain area, where irrigated agriculture is very developed and forms a farmland ecosystem in the inland river basin. The over-exploitation of water resources in the middle-stream area reduces the runoff to the downstream areas, causing degradation of natural ecosystems ( $\mathrm{Ji}$ et al., 2006; Kang et al., 2007; Jia et al., 2009). Therefore, rational utilization and allocation of water resources is extremely important in an inland river basin. This requires accurate estimation of the water budget for the agriculture fields and ET estimation is the key factor of the water loss in the budget.

Published by Copernicus Publications on behalf of the European Geosciences Union. 
To quantify the actual ET of crop fields at the instantaneous, hourly and daily scales, several ET models have been developed and tested in various ecosystems under different climatic conditions throughout the world (Penman, 1948; Monteith, 1965; Priestley and Taylor, 1972; Shuttleworth and Wallace, 1985; Schmugge and André, 1991; Kite, 2000). The most widely used model is the physically-based Penman-Monteith (P-M) model (Monteith, 1965), which assumes that canopies can be regarded as one uniform surface or big leaf (Rana et al., 1997; Allen et al., 2006; Widmoser, 2009), and to which a canopy resistance term is incorporated to determine the stomata influence on ET. Therefore, the representation of canopy resistance is a very important parameter in modeling the actual ET of a crop field using the P-M model.

Two types of canopy resistance (or conductance) models have been used to express the behavior of the canopy resistance: the Jarvis type model and Ball type model. The former relates the canopy resistance to environmental variables at an atmospheric reference height (Javis, 1976; Noilhan and Planton, 1989); the latter correlates canopy resistance to the assimilation rate (Ball et al., 1987; Leuning, 1995; Jacobs and De Bruin, 1997). Although these two types of models have been applied to various canopies and plants (Niyogi and Raman 1997; Ronda et al., 2001), there has been no comparison of the two types of models in terms of their application to the P-M model to simulate the actual ET of crop fields, especially in the arid area of northwest China. The functions and parameters of the models have yet to be evaluated in different studies and in different environmental conditions.

This paper compares results estimated using these two types of canopy resistance models with measured canopy resistance derived from an inverted PM model; the purpose is to evaluate the P-M model with different canopy resistance approaches on modeling actual ET of the irrigated crop fields in an arid climate; and to discuss the variation of ET from a maize field during different stages of the growing season. Results from this study will support the water-efficient agricultural practices and help to improve the irrigation efficiencies of the oases in the inland river basins of Northwestern China.

\section{Evapotranspiration modeling}

\subsection{The Penman-Monteith model}

The P-M model describes the physical process of ET from a vegetative surface, and typically can be written as:

$\lambda \mathrm{E}=\frac{\Delta\left(R_{n}-G\right)+\rho_{a} C_{p}\left(e_{s}-e_{a}\right) / r_{a}}{\Delta+\gamma\left(1+r_{s} / r_{a}\right)}$

where $\lambda$ is latent heat of vaporization of water $\left(\mathrm{MJ} \mathrm{kg}^{-1}\right)$; $\mathrm{E}$ is crop evapotranspiration $\left(\mathrm{mm} \mathrm{s}^{-1}\right) ; \Delta$ is gradient of the water saturation vapour pressure curve $\left(\mathrm{kPa} \mathrm{K}^{-1}\right) ; R_{n}$ is net radiation (W m-2); $G$ is soil heat flux $\left(\mathrm{W} \mathrm{m}^{-2}\right) ; \rho_{a}$ and $C_{p}$ are the density $\left(\mathrm{kg} \mathrm{m}^{-3}\right)$ and specific heat $\left(\mathrm{MJ} \mathrm{kg}^{-1} \mathrm{~K}^{-1}\right)$ of air, respectively; $e_{s}$ and $e_{a}$ are the saturated and actual vapour pressure of air $(\mathrm{kPa})$, respectively; $r_{a}$ is resistance to the turbulent transfer of vapour between source and the reference level $\left(\mathrm{s} \mathrm{m}^{-1}\right) ; \gamma$ is psychrometer constant $\left(\mathrm{kPa} \mathrm{K}^{-1}\right)$; and $r_{s}$ is the canopy resistance $\left(\mathrm{s} \mathrm{m}^{-1}\right)$.

The aerodynamic resistance $r_{a}$ was calculated between the top of the crop and a reference point $z$ sited in the boundary layer above the canopy, following Perrier (1999), as:

$r_{a}=\frac{\ln \left[(z-d) / z_{0}\right] \ln \left[(z-d) /\left(h_{c}-d\right)\right]}{k^{2}} \cdot \frac{1}{u}$

where $z(\mathrm{~m})$ is the reference level at which the horizontal wind speed $u\left(\mathrm{~m} \mathrm{~s}^{-1}\right)$ is measured; $d$ is the zero plane displacement height $(\mathrm{m})$, and is taken equal to $0.67 h_{c}$ (Brutsaert, 1982); $z_{0}$ is the roughness length for momentum (m), approximated as $0.123 h_{c}$ (Brutsaert, 1982); $h_{c}$ is the height of the crop (m); and $k$ is the von Karman's constant, equal to 0.41 .

\subsection{The bulk canopy resistance $r_{s}$}

Certain environmental (Jarvis, 1976) and plant physiological (Ball et al., 1987) factors, such as atmospheric conditions, soil moisture, and the assimilation of plant at the canopy scale, affect the bulk canopy resistance. Two types of bulk canopy resistance models have been applied to express $r_{s}$ : the Noilhan-Planton (N-P) approach (Noilhan and Planton, 1989), also referred to as the Jarvis model (Jarvis, 1976), and the Jacobs- De Bruin (J-D) model (Jacobs and De Bruin, 1997; Ronda et al., 2001) also referred to as the Ball type model (Ball et al., 1987).

\subsubsection{The parameterization of Noilhan-Planton approach}

The N-P bulk canopy resistance $r_{s}$ is a function of incoming solar radiation, mean volumetric water content, vapour pressure deficit of the atmosphere, air temperature and leaf area index (Noilhan and Planton, 1989); it is given by:

$r_{s}=\frac{r_{s \min }}{\mathrm{LAI}} F_{1} F_{2}^{-1} F_{3}^{-1} F_{4}^{-1}$

where $r_{s \min }$ is the minimum stomatal resistance $\left(\mathrm{s} \mathrm{m}^{-1}\right)$, the typical values for $r_{s \min }$ in growing crops range between 40 and $100 \mathrm{~s} \mathrm{~m}^{-1}$ and for mature crops between 250 and $500 \mathrm{~s} \mathrm{~m}^{-1}$ (Tattari et al., 1995). In this study, field observations during the different stages of the maize growing season (initial, development, midseason, and late period) indicated $r_{s \min }$ values of $70 \mathrm{~s} \mathrm{~m}^{-1}, 70 \mathrm{~s} \mathrm{~m}^{-1}, 50 \mathrm{~s} \mathrm{~m}^{-1}$, and $100 \mathrm{~s} \mathrm{~m}^{-1}$ for the respective stages. LAI is the leaf area index $\left(\mathrm{m}^{2} \mathrm{~m}^{-2}\right)$; $F_{1}$ and $F_{4}$ express the dependence of $r_{s}$ on solar radiation and on air temperature, respectively; $F_{2}$ is a function of soil moisture and $F_{3}$ describes the dependence on the atmospheric 
vapour pressure deficit. The parameterization of N-P approach is given as follows (Noilhan and Planton, 1989):

$F_{1}=\frac{1+f}{f+r_{s \min } / r_{s \max }}$

$F_{2}= \begin{cases}1, & w_{2}>w_{\mathrm{cr}} \\ \frac{w_{2}-w_{\text {wilt }}}{w_{\text {cr }}-w_{\text {wilt }},} & w_{\text {wilt }} \leq w_{2} \leq w_{\text {cr }} \\ 0, & w_{2}<w_{\text {wilt }}\end{cases}$

$F_{3}=1-\beta\left(e_{s}\left(T_{s}\right)-e_{a}\right)$

$F_{4}=1.0-0.0016\left(298.0-T_{a}\right)^{2}$

with

$f=0.55 \frac{R_{G}}{R_{G L}} \frac{2}{\mathrm{LAI}}$

where $r_{s \max }$ is the maximum stomatal resistance $\left(\mathrm{s} \mathrm{m}^{-1}\right)$, and was arbitrarily set to $5000 \mathrm{~s} \mathrm{~m}^{-1}$ (Noilhan and Planton, 1989); $w_{2}$ is the mean volumetric water of the soil column $\left(\mathrm{m}^{3} \mathrm{~m}^{-3}\right) ; w_{\mathrm{cr}}$ is the soil water content below which transpiration is stressed by soil moisture, taken as $0.75 w_{\text {sat }} ; w_{\text {wilt }}$ is the plant permanent wilting point. In this study, the saturated soil water content $w_{\text {sat }}$ is set as $0.40 \mathrm{~m}^{3} \mathrm{~m}^{-3}$ and wilting point as $0.11 \mathrm{~m}^{3} \mathrm{~m}^{-3}$ for sandy loam in the field. $T_{s}$ and $T_{a}$ are the surface and air temperature at the crop height level (K). $\beta$ is a species-dependent empirical parameter and set to $0.0238 \mathrm{hPa}^{-1}$ for maize (Ács, 1994) in this study. $R_{G}$ is the incoming solar radiation ( $\mathrm{W} \mathrm{m}^{-2}$ ), and $R_{G L}$ is the limit value of $100 \mathrm{~W} \mathrm{~m}^{-2}$ for crops (Noilhan and Planton, 1989).

\subsubsection{Parameterization of the Jacobs-De Bruin model}

The J-D model (Jacobs and De Bruin, 1997) is based on plant physiology, which uses a correlation relationship between the leaf stomatal conductance and the net photosynthetic rate at leaf scale, and then up-scales the conductance from a leaf to a canopy:

$1 / r_{s}=\int_{0}^{\mathrm{LAI}}\left[1.6 A_{n} /\left(C_{s}-C_{i}\right)\right] d L$

where $A_{n}$ is the net photosynthetic rate $\left(\mathrm{mg} \mathrm{m}^{-2} \mathrm{~s}^{-1}\right) ; C_{s}$ and $C_{i}$ are the $\mathrm{CO}_{2}$ concentration at the leaf surface and in the sub-stomatal cavity $\left(\mathrm{mg} \mathrm{m}^{-3}\right)$, respectively; and $L$ is the leaf-area index $\left(\mathrm{m}^{2} \mathrm{~m}^{-2}\right)$ for the integration interval boundaries, which sums to LAI, the total leaf area index over the entire canopy depth.

In the J-D model, the net photosynthetic rate at leaf scale is given by

$A_{n}=\left(A_{m}+R_{d}\right)\left[1-\exp \left(\frac{-\varepsilon_{i} I}{A_{m}+R_{d}}\right)\right]-R_{d}$

where $A_{m}$ is the photosynthetic rate at infinite light intensity $\left(\mathrm{mg} \mathrm{m}^{-2} \mathrm{~s}^{-1}\right) ; R_{d}$ is the rate of dark respiration $\left(\mathrm{mg} \mathrm{m}^{-2} \mathrm{~s}^{-1}\right) ; \varepsilon_{i}$ is the initial light use efficiency $\left(\mathrm{mg} \mathrm{J}^{-1}\right)$, and $I$ is the amount of photosynthetically active radiation $\left(\mathrm{W} \mathrm{m}^{-2}\right)$. Here, $R_{d}$ is estimated as $0.11 A_{m}$. The response of $A_{m}$ to $\mathrm{CO}_{2}$ is modeled as

$A_{m}=A_{m, \max }\left\{1-e^{-\left[g_{m}\left(C_{i}-\Gamma\right) / A_{m, \max }\right]}\right\}$

where $A_{m, \max }$ is the maximal primary productivity under light conditions and high $\mathrm{CO}_{2}$ concentrations $\left(\mathrm{mg} \mathrm{m}^{-2} \mathrm{~s}^{-1}\right)$; $g_{m}$ is the mesophyll conductance $\left(\mathrm{mm} \mathrm{s}^{-1}\right)$, and $\Gamma$ is the $\mathrm{CO}_{2}$ compensation point $\left(\mathrm{mg} \mathrm{m}^{-3}\right)$.

The parameters $g_{m}, A_{\mathrm{m} \text {,max }}$ and $\Gamma$ are the functions of leaf temperature $T_{C}(\mathrm{~K})$ and computed as:

$X\left(T_{c}\right)=\frac{X\left(T_{c}=298 \mathrm{~K}\right) Q_{10}^{\left(T_{c}-298\right) / 10}}{\left[1+e^{0.3\left(T_{1}-T_{c}\right)}\right]\left[1+e^{0.3\left(T_{c}-T_{2}\right)}\right]}$

$\Gamma\left(T_{c}\right)=\Gamma\left(T_{c}=298 \mathrm{~K}\right) Q_{10}^{\left(T_{c}-298\right) / 10}$

where $X$ denotes $g_{m}$ or $A_{\mathrm{m}, \max }$, and $T_{1}$ and $T_{2}$ are reference temperatures (K). $T_{1}$ and $T_{2}$ for $g_{m}$ are set as $286 \mathrm{~K}$ and $309 \mathrm{~K}$, respectively, while $T_{1}$ and $T_{2}$ for $A_{\mathrm{m}, \max }$ are set as $286 \mathrm{~K}$ and $311 \mathrm{~K}$, respectively. As in the J-D model, the values of $g_{m}\left(T_{c}=298\right)$ and $A_{\mathrm{m}, \max }\left(T_{c}=298\right)$ are set as $17.5 \mathrm{~mm} \mathrm{~s}^{-1}$ and $1.7 \mathrm{mg} \mathrm{m}^{-2} \mathrm{~s}^{-1}$ for maize, respectively; the values of $Q_{10}$ is set as 2.0 for maize; and $\Gamma\left(T_{c}=298 \mathrm{~K}\right)$ and $Q_{10}$ are set as $4.3 \rho_{a}$ and 1.5 for maize, respectively.

In Eq. (10) the light use efficiency $\varepsilon_{i}$ is a function of $C_{s}$, $\Gamma$, and the initial (at low light conditions) light use efficiency $\varepsilon_{0}$ (Jacobs and De Bruin, 1997):

$\varepsilon_{i}=\varepsilon_{0} \frac{C_{s}-\Gamma}{C_{s}+2 \Gamma}$

The parameter values for $\varepsilon_{0}$ is have been derived by Collatz et al. (1991, 1992). The value for maize ( $C_{4}$ plant) is set as $0.014 \mathrm{mg} \mathrm{J}^{-1}$.

In laboratory experiments the internal $\mathrm{CO}_{2}$ concentration $C_{i}$ is often found to be a fraction of the external $\mathrm{CO}_{2}$ concentration (Ronda et al., 2001). Zhang and Nobel (1996) proposed the following formula to express the relationship between $\left(C_{i}-\Gamma\right) /\left(C_{s}-\Gamma\right)$ and the water vapour deficit:

$\frac{C_{i}-\Gamma}{C_{s}-\Gamma}=f_{0}-a_{d} D_{s}$

where $f_{0}$ and $a_{d}$ are empirically found as regression coefficients. A typical value for $f_{0}$ is 0.85 and a typical value for $a_{d}$ is $0.015 \mathrm{Kpa}^{-1}$ for $\mathrm{C}_{4}$ plants (Jacobs and De Bruin, 1997; Ronda et al., 2001). $D_{s}$ is the vapour pressure deficit at plant level $(\mathrm{kPa})$. 


\section{Site description and field measurements}

\subsection{Site description}

This work was undertaken on fields of maize during the 2008 growing season. The fields are located in the agricultural water-saving experimental plot $(1 \mathrm{~km} \times 1 \mathrm{~km})$ of the Linze Inland River Basin Comprehensive Research Station $\left(39^{\circ}\right.$ $20^{\prime} \mathrm{N}, 100^{\circ} 08^{\prime}$ E, elevation $1378 \mathrm{~m}$ ), Chinese Ecosystem Research Network, Cold and Arid Regions Environmental and Engineering Research Institute, Chinese Academy of Sciences. The site is located in the central area of the Zhangye irrigation oases along the middle stream of the Heihe River, which is an inland river in the arid area of northwest China. The terrain is relatively flat with a mean slope in the vicinity of the site ranging between 2.1 and $4.5 \%$. The maize canopy extended for over a kilometer in all directions.

The site is characterized by a typical continental arid climate: dry and hot in summer and cold in winter. The normal annual mean air temperature is $7.6^{\circ} \mathrm{C}$, with an absolute maximum of $39.1^{\circ} \mathrm{C}$ and an absolute minimum of $-27.3^{\circ} \mathrm{C}$. Mean annual precipitation is $117 \mathrm{~mm}$, with nearly $70 \%$ concentrated in the months from July to September. Mean annual pan evaporation is $2390 \mathrm{~mm}$. Mean annual wind velocity is $3.2 \mathrm{~m} \mathrm{~s}^{-1}$, and the prevailing wind direction is northwest (Ji et al., 2007, 2009). The soil type is a sandy loam (sand: $59.0 \%$; silt: $36.3 \%$; clay: $4.7 \%$ ). Soil organic matter and $\mathrm{pH}$ value are $0.72 \%$ and 8.86 , respectively. Fertilizes were applied at a rate of $708 \mathrm{~kg} \mathrm{~N}$ per hectare, $179 \mathrm{~kg} \mathrm{P}$ per ha and $75 \mathrm{~kg} \mathrm{~K}$ per ha during the growing season in 2008 , respectively. The staple crop in the oasis is maize. Surface irrigation account for $95 \%$ of the total irrigated area, and consists mainly of the border irrigation.

\subsection{Field measurements}

Continuous measurements were carried out at the study site during the maize growing season from 26 May to 30 September 2008. Eddy covariance technique was used to measure the fluctuations of wind speed, temperature, carbon dioxide, and water vapour above the canopy. The eddy covariance system consists of a three dimensional (3-D) sonic anemometer (HS-50, Gill Solent Istruments, Lymington, Hampshire, UK) and an open-path infrared gas analyzer (LI-7500, LICOR Inc., Lincoln, NE, USA). Variances and covariances were calculated from the $20 \mathrm{~Hz}$ raw data. Vertical fluxes of momentum, sensible heat, carbon dioxide, and water vapour were determined by means of 1) the 3-D sonic anemometer to sample the three components of wind speed $(u, v, w)$ and virtual acoustic temperature (the speed of sound) $T$ and 2) an open-path infrared gas analyzer for measurement of water vapour and carbon dioxide mole densities above the crop field. The fast response sensors were mounted at a height of $2 \mathrm{~m}$ above the crop canopy level (i.e. the sensor height varied during the measurement campaigns) (Kaimal and Finnigan,
1994). The open sides of the asymmetric sonic anemometers were exposed to the north-west at the experimental plot. The open-path infrared gas analyzer were mounted $0.2 \mathrm{~m}$ below the sonic anemometer and displaced $0.3 \mathrm{~m}$ laterally and perpendicular to the predominating wind direction in order to minimize flux loss due to vertical (Kristensen et al., 1997) and longitudinal (Massman, 2000) sensor separation, respectively. Data were recorded on a personal computer inside of a small hut $50 \mathrm{~m}$ from the site.

All raw data were saved using the EDDYMEAS software (Kolle and Rebmann, 2007) for post-processing by $E D$ DYSOFT software (Kolle and Rebmann, 2007). Half-hourly mean eddy fluxes over the crop field were calculated as the covariance between turbulent fluctuations of the vertical wind speed and the scalar mixing ratios calculated by Reynolds averaging of 30-min blocks of data. Following the recommendations of McMillen (1988), a two dimensional coordinate rotation was applied to force the average vertical wind speed $(w)$ to zero and to align the horizontal wind $(u)$ to mean wind direction. Both the $\mathrm{CO}_{2}$ flux and latent flux were corrected for density effects by the method described by Webb et al. (1980). The post-processing of flux data also includes other necessary corrections, such as convert sonic temperature to actual temperature correction, frequency response correction. The detailed description can also be found in Kolle and Rebmann (2007). As a result, latent and sensible heat fluxes were calculated as:

$\lambda \bar{E}_{E C}=\lambda\left(1+\bar{\chi}_{v}\right)\left(\overline{w^{\prime} c_{v}^{\prime}}+\frac{\bar{c}_{v}}{\bar{T}} \frac{\bar{H}}{\bar{\rho} c_{p}}\right)$

$\bar{H}=\bar{\rho} c_{p} \overline{w^{\prime} T^{\prime}}$

where $E_{E C}$ is water vapor flux $\left(\mathrm{mmol} \mathrm{m}{ }^{-2} \mathrm{~s}^{-1}\right) ; \chi_{v}$ is the ratio of vapour pressure to atmospheric pressure (-); $c_{v}$ is the molar concentration of water vapour $\left(\mathrm{mmol} \mathrm{m}^{-3}\right) ; H$ is sensible heat flux $\left(\mathrm{W} \mathrm{m}^{-2}\right) ; T$ is the ambient air temperature $(\mathrm{K})$; and $\rho$ is density of moist air $\left(\mathrm{kg} \mathrm{m}^{-3}\right)$; overbars denote time averages and primes denote the departures. Positive fluxes indicate mass and energy transfer from the surface to the atmosphere, and negative from the atmosphere to the surface.

The eddy covariance technique is limited by missing or rejected measurements due to system failures, maintenance and calibration, and improper weather conditions. In this study, the following gap-filling procedures were employed: short gaps less than $6 \mathrm{~h}$ were filled by linear interpolation and large gaps were filled by means of the look-up table approach or, if not possible, by the mean diurnal variation method (Falge et al., 2001).

The EVINS Environmental Monitoring System (IMKO Micromodultechnik GnbH, Ettlingen, Germany) was mounted about $60 \mathrm{~m}$ from the eddy covariance tower in this study field. The detailed description of measured environmental variables by the EVINS can be found in Table 1 . All EVINS data were measured every $10 \mathrm{~min}$ and averaged 
Table 1. The information of measured environmental variables by the EVINS Environmental Monitoring System.

\begin{tabular}{|c|c|c|}
\hline Variables & Sensors & Observation positions \\
\hline Net radiation & CNR-1 (Kipp \& Zonen, Delft, The Netherlands) & $2 \mathrm{~m}$ above the canopy \\
\hline $\begin{array}{l}\text { Photosynthetically } \\
\text { active radiation }\end{array}$ & LI-190 (LI-COR Inc., Lincoln, NE, USA) & $2 \mathrm{~m}$ above the canopy \\
\hline Air temperature & HMP45D (Vaisala, Helsinki, Finland) & $2 \mathrm{~m}$ above the canopy \\
\hline Relative humidity & HMP45D (Vaisala, Helsinki, Finland) & $2 \mathrm{~m}$ above the canopy \\
\hline Air pressure & PTB100 (Vaisala, Helsinki, Finland) & $2 \mathrm{~m}$ above the canopy \\
\hline Wind speed & $\begin{array}{l}\text { LISA cup anemometer (Siggelkow GmbH, } \\
\text { Germany) }\end{array}$ & $2 \mathrm{~m}$ above the canopy \\
\hline Wind direction & $\begin{array}{l}\text { Young } 8100 \text { (Siggelkow GmbH, Hamburg, } \\
\text { Hamburg, Germany) }\end{array}$ & $2 \mathrm{~m}$ above the canopy \\
\hline $\begin{array}{l}\text { Canopy/surface } \\
\text { temperature }\end{array}$ & $\begin{array}{l}\text { PS12AF1 surface Pyrometer (Keller HCM } \\
\text { GmbH, Ibbenbüren-Laggenbeck, Germany) } \\
\text { Pt100 (IMKO GmbH, Ettlingen, Germany) }\end{array}$ & $2 \mathrm{~m}$ above the canopy \\
\hline Soil temperature & $\begin{array}{l}\text { TRIME-IT (IMKO GmbH, Ettlingen, } \\
\text { Germany) }\end{array}$ & $\begin{array}{l}5,10,20,40,80 \text { and } \\
120 \mathrm{~cm} \text { depths in the soil }\end{array}$ \\
\hline $\begin{array}{l}\text { Volumetric soil water } \\
\text { content }\end{array}$ & $\begin{array}{l}\text { Three HFP-01 heat flux plates (Hukseflux } \\
\text { Thermal Sensors, Delft, The Netherlands) }\end{array}$ & $\begin{array}{l}10,20,50,100,200, \\
300 \mathrm{~cm} \text { depths in the soil }\end{array}$ \\
\hline Soil heat fluxes & RG50 tipping bucket rainfall gauges & $0.05 \mathrm{~m}$ in the soil surface \\
\hline Precipitation & $\begin{array}{l}\text { (SEBA Hydrometrie GmbH, Gewerbestr, } \\
\text { Germany) }\end{array}$ & the top of canopy \\
\hline
\end{tabular}

Table 2. Mean daytime meteorological and ecological elements on selected days.

\begin{tabular}{lcccccc}
\hline $\begin{array}{l}\text { DOY } \\
\text { (day of year })\end{array}$ & $\begin{array}{c}R_{n} \\
\left(\mathrm{~W} \mathrm{~m}^{-2}\right)\end{array}$ & $\begin{array}{c}\text { PAR } \\
\left(\mu \mathrm{mol} \mathrm{m}^{-2}\right)\end{array}$ & $\begin{array}{c}T_{a} \\
(\mathrm{~K})\end{array}$ & $\begin{array}{c}D_{s} \\
(\mathrm{kPa})\end{array}$ & $\begin{array}{c}w_{2} \\
\left(\mathrm{~m}^{3} \mathrm{~m}^{-3}\right)\end{array}$ & $\begin{array}{c}\text { LAI } \\
\left(\mathrm{m}^{2} \mathrm{~m}^{-2}\right)\end{array}$ \\
\hline 130 & 491.7 & 1385.9 & 305.3 & 3.0 & 31.3 & 0.3 \\
162 & 512.7 & 1454.6 & 307.9 & 3.3 & 30.8 & 2.0 \\
195 & 523.2 & 1472.0 & 308.7 & 2.2 & 28.5 & 4.8 \\
229 & 479.2 & 1294.6 & 307.3 & 2.5 & 27.8 & 3.2 \\
\hline
\end{tabular}

every $30 \mathrm{~min}$, and recorded on Trimelogger (IMKO GmbH, Ettlingen, Germany). In addition, the measured canopy temperature by PS12AF1 surface Pyrometer (Keller HCM $\mathrm{GmbH}$, Ibbenbüren-Laggenbeck, Germany) is in agreement with the actual canopy temperature when the canopy covers fully soil surface. However, it is found that there are some distortions when the canopy is sparse during the early stage of maize growing season. In order to resolve the problem, the regression relationship was established between canopy temperature and air temperature for the site and period when the canopy covers fully the soil surface. Then, the resulting equations were used to fill in the canopy temperature during the period of sparse canopy.

The stomatal conductance was measured hourly at four levels in the canopy by a LI-COR 6400 (LI-COR Inc., Lincoln, NE, USA) in the maize field for 4 days over the 2008 growing season. The canopy was divided into four levels with each level representing the $25 \%$ of the canopy. For each level, the leaves with orientations of east, west, north and south were selected. Plant height, leaf position and area were regularly measured throughout the maize growing season. The green leaf area index of maize was measured with a LI-3100 area meter (LI-COR Inc., Lincoln, NE, USA).

\section{Results and discussion}

\subsection{Diurnal variations in stomatal conductance during the maize growing season}

Diurnal variations in stomatal conductance were measured on selected days of the growing season, as presented in Fig. 1. The mean values of net radiation $R_{n}$, photosynthetically active radiation PAR, air temperature at crop height $T_{a}$, vapour pressure deficit $D_{s}$, soil water content $w_{2}$ and green 

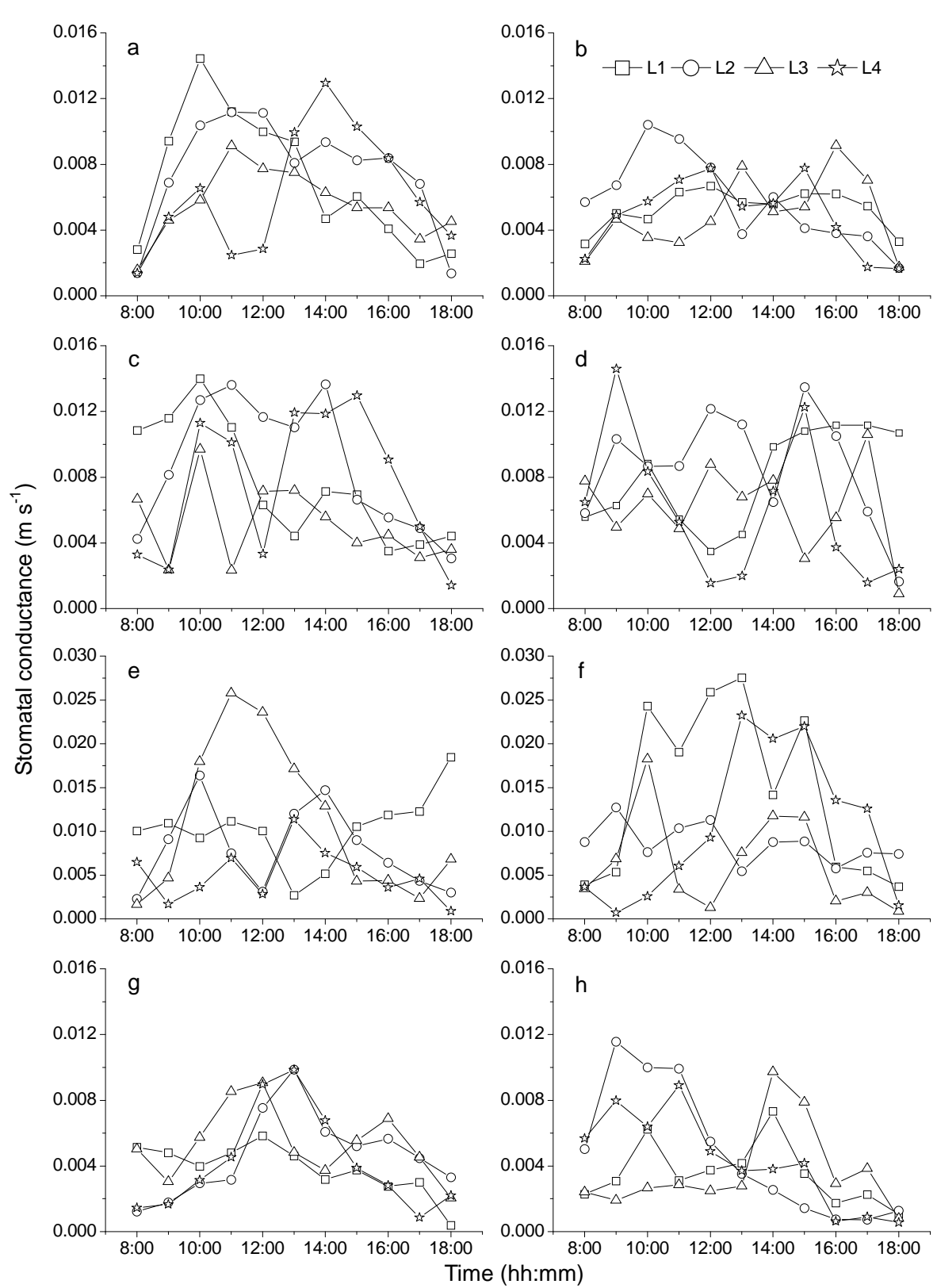

Fig. 1. Diurnal variation in stomatal conductance in the maize canopy. The days are DOY 130 (a), (b), DOY 162 (c),(d), DOY 195 (e), (f) and DOY 229 (g), (h). L1, L2, L3 and L4 refer to the levels at the top layer, above middle layer, below middle layer and bottom layer of the canopy. a, c, e and $\mathrm{g}$ of the left column have the leaf orientation east-west, and b, d, f, and $\mathrm{h}$ of the right column have the leaf orientation south-north.

leaf area index LAI during the daytime hours (from 08:00 to 18:00 LT) of the observation days in the different stages of crop growing season are listed in Table 2.

Diurnal variation in stomatal conductance has common patterns for the different stages of maize growing season. The stomatal conductance varies with a lower value in the morning and afternoon, and a higher value in the midday, depending on solar radiation and vapour pressure deficit. The response of stomatal conductance to vapour pressure deficit, photosynthetically active radiation and air temperature is, respectively shown in Figs. 2-4. The responses reflect a common characteristic in conductance for water exchange between the plant and atmosphere at both the leaf and canopy scales. The diurnal variation in leaf stomatal conductance of maize in this study field has higher values in the morning than in the afternoon, and lower values at midday (13:00 LT) than before and after about 13:00 LT. The lower stomatal conductance during the afternoon and midday can be attributed to 


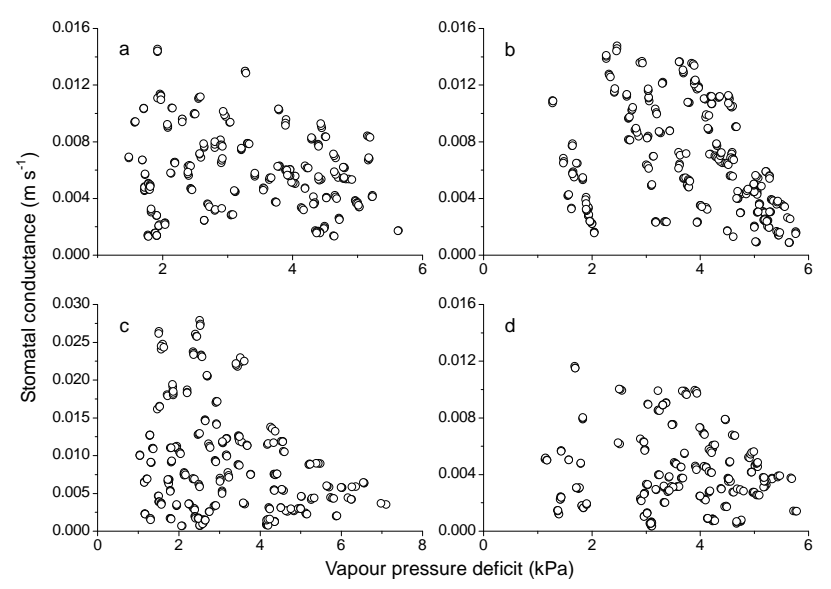

Fig. 2. Response of stomatal conductance to vapour pressure deficit at the four levels in the maize canopy on DOY 130 (a), DOY 162 (b), DOY 195 (c), and DOY 229 (d), respectively.

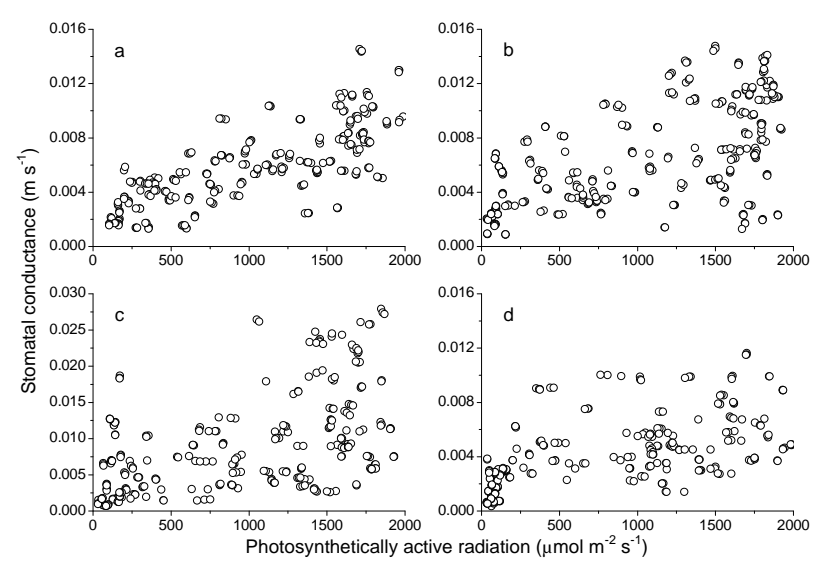

Fig. 3. Response of stomatal conductance to photosynthetically active radiation at the four levels in the maize canopy on DOY 130 (a), DOY 162 (b), DOY 195 (c), and DOY 229 (d), respectively.

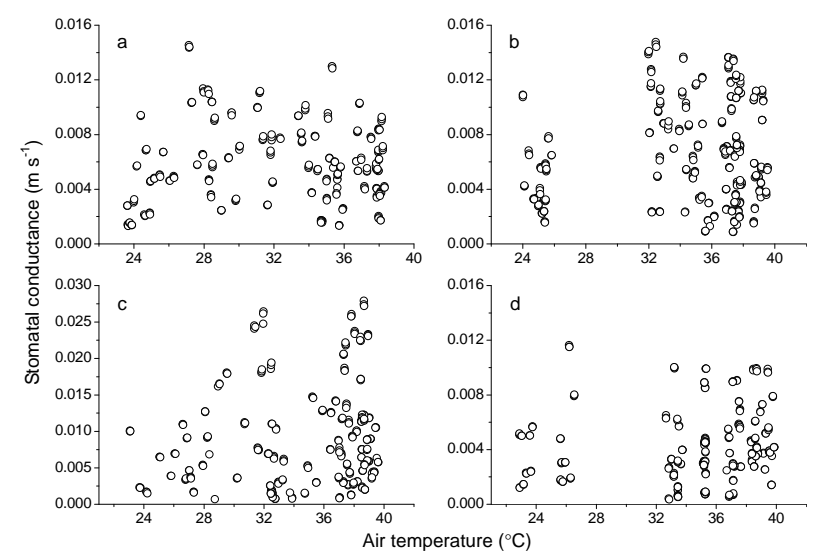

Fig. 4. Response of stomatal conductance to air temperature at the four levels in the maize canopy on DOY 130 (a), DOY 162 (b), DOY 195 (c), and DOY 229 (d), respectively.

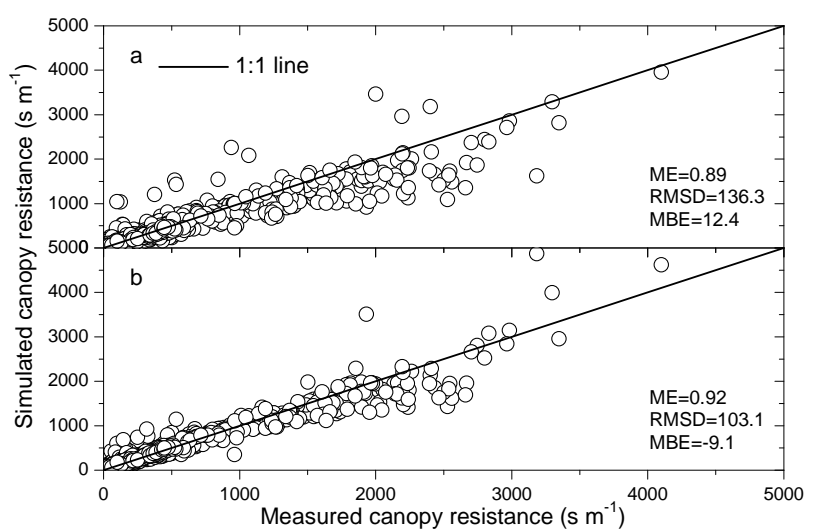

Fig. 5. Comparison between measured bulk canopy resistance derived from P-M model and predicted values obtained by the J-D (a) and the N-P (b) approach.

the higher water vapour deficit (midday depression of photosynthesis). A lower stomatal conductance at midday can be explained by a limitation of photosynthesis due to the stomatal closure to prevent the water loss from the most intensive solar radiation and higher temperatures. However, the lower values of stomatal conductance occur at varies times depending on the physiological adaptation (stomatal control) of leaf to changes in their environment, such as absorbed PAR by leaf, air temperature, vapour pressure deficit, soil water content, and so on.

Stomatal conductance increases from the beginning to the middle of the maize growing season, and then decreases as the season progresses. The daytime mean values of stomatal conductance were measured to be $5.90 \mathrm{~mm} \mathrm{~s}^{-1}$ on day of year (DOY)130, $7.21 \mathrm{~mm} \mathrm{~s}^{-1}$ on DOY 162, $9.26 \mathrm{~mm} \mathrm{~s}^{-1}$ on DOY 195 and $4.29 \mathrm{~mm} \mathrm{~s}^{-1}$ on DOY 229. This indicates that the stomatal conductance increases with increasing PAR and with decreases vapour pressure deficit.

\subsection{Test of the J-D and N-P approaches in the determination of the canopy resistance}

To test the J-D and N-P approaches for determining the bulk canopy resistance, the half-hourly bulk canopy resistance values derived from the P-M model based on the measured ET from the eddy covariance system was compared with those simulated using the J-D and N-P approaches. Using the P-M model-derived bulk canopy resistance as the measured value, three statistical tests were performed: model efficiency (ME), root mean square deviation (RMSD), and mean bias error (MBE) (Ji et al., 2009).

A comparison of the J-D bulk canopy resistance estimates to the measured values yielded ME, RMSD, and MBE values of $0.89 \mathrm{~s} \mathrm{~m}^{-1}, 136.3 \mathrm{~s} \mathrm{~m}^{-1}$, and $12.4 \mathrm{~s} \mathrm{~m}^{-1}$, respectively (Fig. 5a). The N-P approach better in simulating bulk canopy resistance yielding ME, RMSD, and MBE values 


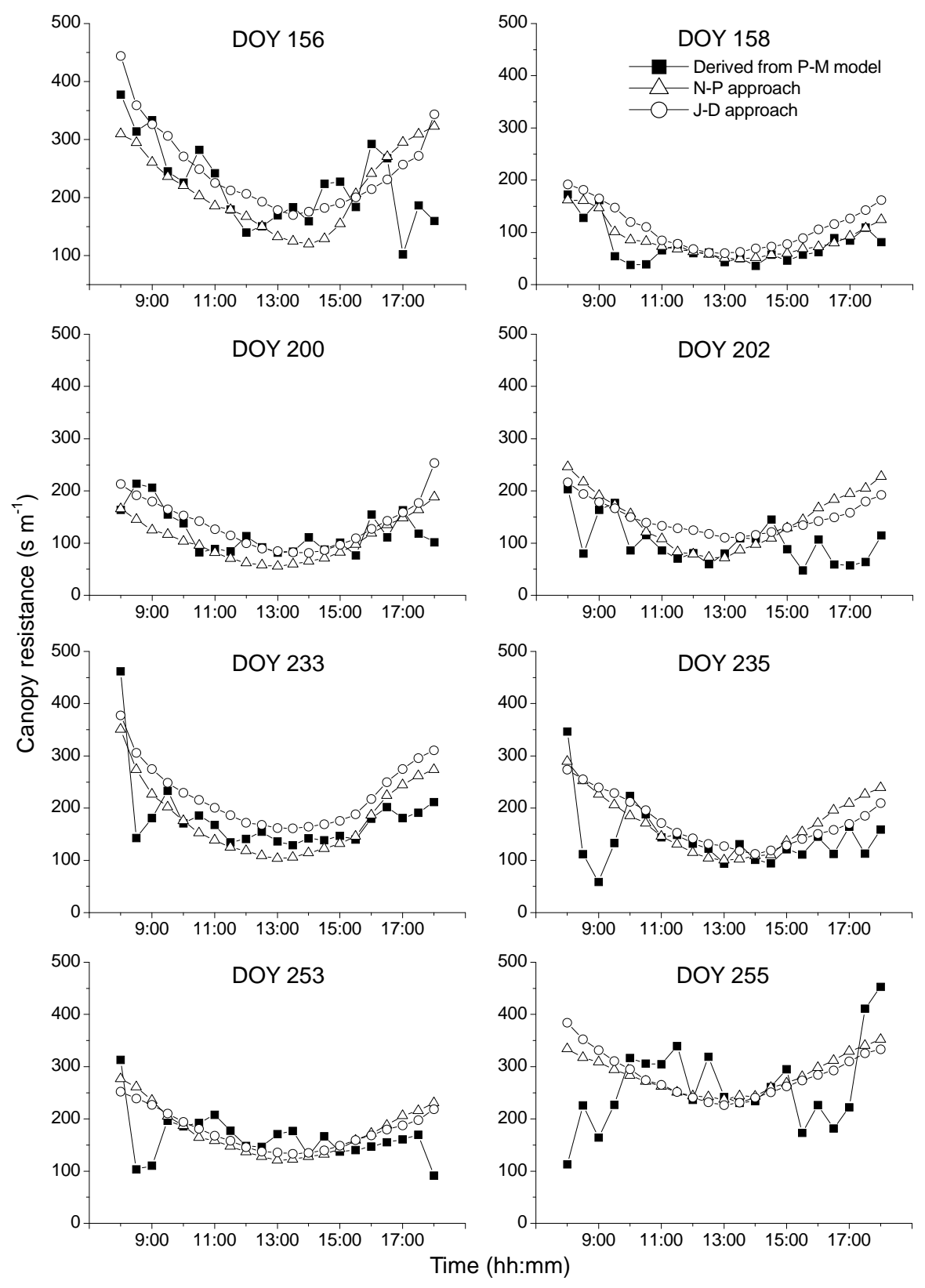

Fig. 6. Comparison of the measured and the simulated half-hourly bulk canopy resistance on the days before and after irrigation during the maize growing season.

of $0.92 \mathrm{~s} \mathrm{~m}^{-1}, 103.1 \mathrm{~s} \mathrm{~m}^{-1}$, and $-9.1 \mathrm{~s} \mathrm{~m}^{-1}$, respectively (Fig. 5b). From the MBE values given in Fig. 5, it can be seen that the J-D approach overestimated the bulk canopy resistance. Therefore, the N-P approach is more suitable than the J-D approach in the simulation of bulk canopy resistance of the irrigated maize field under the arid climatic conditions of the study.

\subsection{Diurnal variation in the bulk canopy resistance}

In order to investigate the effect of irrigation, days were selected before and after irrigation. The daily variation of the bulk canopy resistance was then simulated for the selected days using the two approaches as shown in Fig. 6. During the entire maize growing season in 2008, surface irrigation (i.e., small level-basin irrigation) occurred eight times for a total water depth of $960 \mathrm{~mm}$. Each irrigation used $120 \mathrm{~mm}$ over approximately two weeks. The diurnal variation in the bulk 
Table 3. Mean daytime meteorological and ecological elements on selected days before and after irrigation.

\begin{tabular}{lllllllll}
\hline DOY & $\begin{array}{l}R_{n} \\
\left(\mathrm{~W} \mathrm{~m}^{-2}\right)\end{array}$ & $\begin{array}{l}\text { PAR } \\
\left(\mu \mathrm{mol} \mathrm{m} \mathrm{m}^{-2} \mathrm{~s}^{-1}\right)\end{array}$ & $\begin{array}{l}T_{a} \\
(\mathrm{~K})\end{array}$ & $\begin{array}{l}D_{s} \\
(\mathrm{kPa})\end{array}$ & $\begin{array}{l}w_{2} \\
\left(\mathrm{~m}^{3} \mathrm{~m}^{-3}\right)\end{array}$ & $\begin{array}{l}\mathrm{LAI} \\
\left(\mathrm{m}^{2} \mathrm{~m}^{-2}\right)\end{array}$ & $\begin{array}{l}C_{s} \\
\left(\mathrm{mmol} \mathrm{m}^{-3}\right)\end{array}$ & $\begin{array}{l}u \\
\left(\mathrm{~m} \mathrm{~s}^{-1}\right)\end{array}$ \\
\hline 156 & 187.7 & 561.2 & 294.8 & 1.6 & 26.4 & 1.6 & 12.1 & 3.1 \\
158 & 382.2 & 1220.1 & 300.0 & 2.2 & 31.6 & 1.6 & 10.5 & 1.3 \\
200 & 480.0 & 1410.5 & 301.7 & 2.5 & 26.2 & 4.8 & 12.4 & 1.3 \\
202 & 291.6 & 896.3 & 299.5 & 1.7 & 30.9 & 4.8 & 12.4 & 1.2 \\
233 & 464.0 & 1265.0 & 295.3 & 1.8 & 26.2 & 3.1 & 12.8 & 1.4 \\
235 & 415.5 & 1028.1 & 297.1 & 2.2 & 32.2 & 3.1 & 12.7 & 1.5 \\
253 & 428.1 & 1087.7 & 295.2 & 2.0 & 26.5 & 2.2 & 10.6 & 1.1 \\
255 & 404.3 & 955.6 & 298.4 & 2.4 & 31.3 & 2.2 & 13.5 & 1.0 \\
\hline
\end{tabular}

canopy resistance on days before and after irrigation were simulated on DOY 157, DOY 201, DOY 234 and DOY 254, respectively. Table 3 shows the mean values of the meteorological and ecological elements in the daytime (from 08:00 to $18: 00 \mathrm{LT}$ ) on the selected days during the different stages of the maize growing season.

Half-hourly values of bulk canopy resistance exhibited a reverse parabolic pattern, reaching the minimum value near mid-day (13:00 LT) during the different stages of the maize growing season. The values were higher in the morning and afternoon, and lower at the midday, depending on solar radiation. The daily variation of resistance indicates that ET increases with net radiation. It was found that, except in a condition of low soil water content, the bulk canopy resistance was larger in the morning than that in the afternoon (Fig. 6). This is due to the decrease of the water vapour deficit and the more intensive solar radiation (or PAR) in the afternoon.

Figure 6 indicates that both the J-D and N-P approaches overestimated the bulk canopy resistance in the morning and afternoon of the sunny day. Under dry soil conditions before irrigation, the J-D approach slightly overestimated the bulk canopy resistance during midday except during the later stages of the maize growing season, while the N-P approach underestimated it. When soil was wet after irrigation, both approaches got the overestimated the values for bulk canopy resistance. However, the bulk canopy resistance of the maize field simulated by the N-P approach was a better fit with the data derived from P-M model, as compared to the results obtained using the J-D approach.

\subsection{Simulation of evapotranspiration}

Figure 7 compares the measured half-hourly latent heat flux obtained by the eddy covariance system to those simulated by the P-M model using the J-D (Fig. 7a) and the N-P (Fig. 7b) approaches during the maize growing season in 2008. In Fig. 7, all the measured and simulated latent heat fluxes are distributed around the one-to-one line. The values of ME, RMSD, and MBE were $0.67 \mathrm{~W} \mathrm{~m}^{-2}, 78.1 \mathrm{~W} \mathrm{~m}^{-2}$ and $-40.3 \mathrm{~W} \mathrm{~m}^{-2}$, respectively, for the $\mathrm{J}-\mathrm{D}$ approach, and

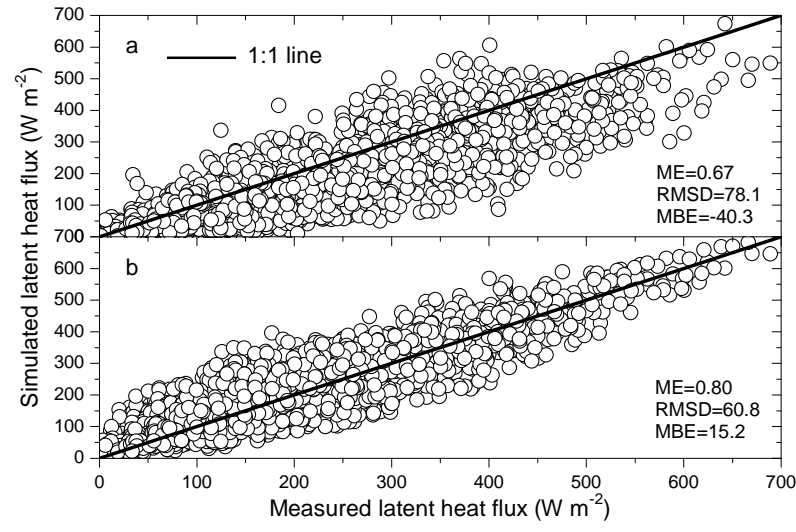

Fig. 7. Comparison between the measured and the simulated halfhourly evapotranspiration by P-M model using the J-D (a) and the N-P (b) bulk canopy resistance approach.

$0.80 \mathrm{~W} \mathrm{~m}^{-2}, 60.8 \mathrm{~W} \mathrm{~m}^{-2}$, and $15.2 \mathrm{~W} \mathrm{~m}^{-2}$, respectively, for the N-P approach. In addition, the energy balance ration $\left(\sum(\lambda \mathrm{E}+H) / \sum(\mathrm{Rn}-G-S)\right)$ of flux measured by the eddy covariance system was 0.86 during the maize growing season, where $S$ is the rate of change of heat storage (air and biomass) between the soil surface and level of the eddy covariance instrumentation. The energy imbalance may also contribute to the difference in the latent heat fluxes derived from the simulated and measured results. As a whole, the half-hourly latent heat fluxes simulated by the P-M model using both bulk canopy resistance approaches generally corresponded well to results obtained using the measured fluxes; overall, the N-P approach performed better than the J-D approach.

\subsection{Diurnal variation of latent heat flux}

Figure 8 shows the diurnal variation in the half-hourly measured and simulated latent heat flux corresponding to the data presented in Fig. 6. The latent heat fluxes reach the maximum value near mid-day. The simulated and the measured daily variations of latent heat fluxes correspond well for both 

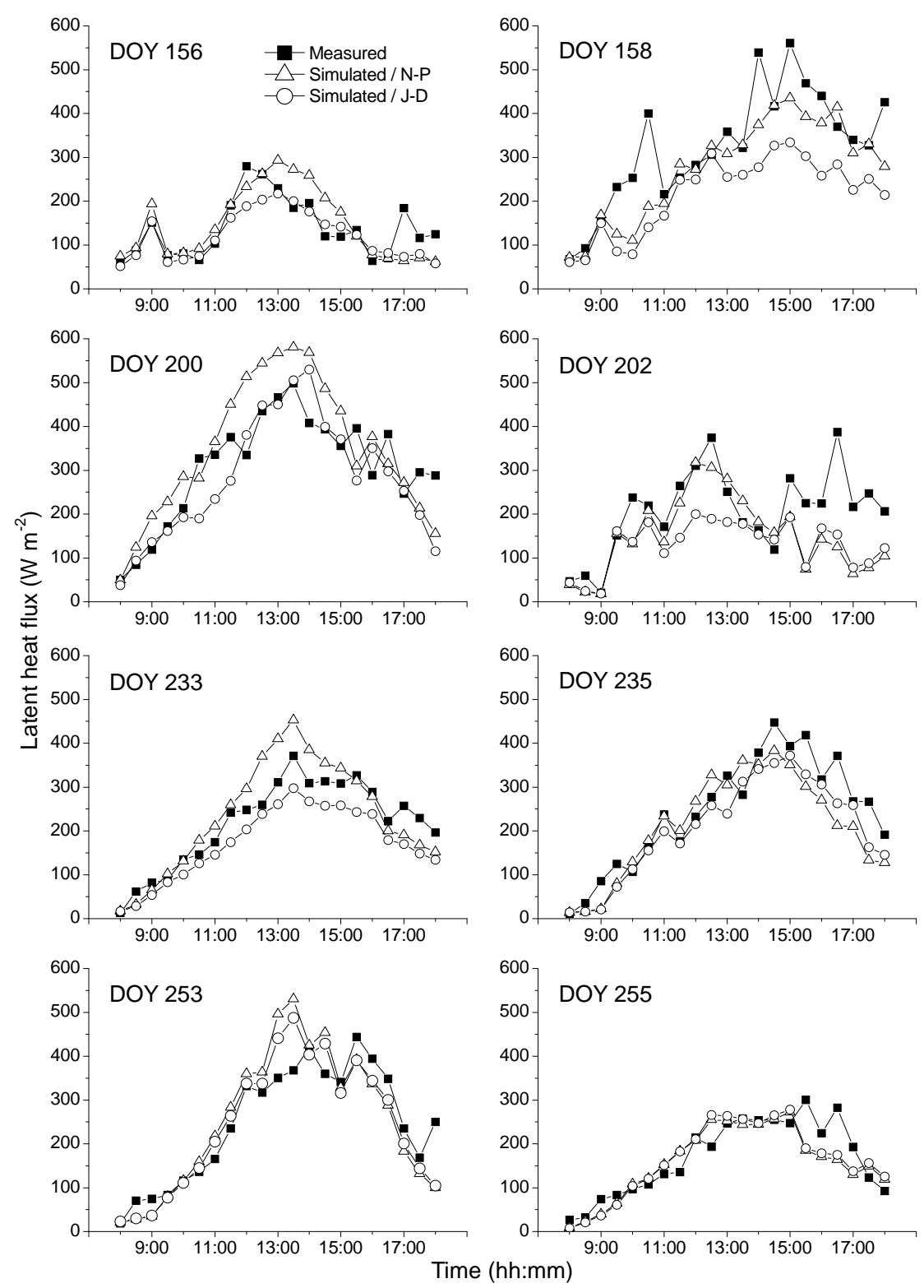

Fig. 8. Measured and modeled courses of half-hourly latent heat flux on days before and after irrigation during the maize growing season.

bulk canopy resistance approaches. Nevertheless, the P-M model using J-D bulk canopy resistance approach slightly underestimated the latent heat flux during the maize growing season. The P-M model using the N-P bulk canopy resistance approach tended to overestimate the latent heat flux under the dry soil conditions (on DOY 156, DOY 200, DOY 233 and DOY 253), and to underestimate slightly the latent heat flux under the wet soil conditions. Those may be mainly attributed to the differences in the values of the bulk canopy resistance by the two approaches. However, the difference between the values obtained with the J-D and the N-P approaches were generally small for both dry and wet soil conditions (DOY 253 and DOY 255).
The maize field for this study was sufficiently supplied with water, and the soil water contents were generally above $0.27 \mathrm{~m}^{3} \mathrm{~m}^{-3}$ (based on the field measurements by the authors), below which transpiration is restricted by soil moisture. This indicates that the P-M model using the J-D and the N-P approaches can be applied to relatively homogenous and irrigated agricultural fields, such as those in this paper. On the other hand, Fig. 8 also indicates the P-M model performed better using the J-D bulk canopy approach than using the N-P approach when the soil was dry (before irrigation). Under wet conditions after irrigation, the P-M model using the N-P approach yielded better results. 
The P-M model using the J-D and the N-P bulk canopy resistance approaches seems to provide realistic diurnal patterns for the half-hourly latent heat flux under well-watered and slightly stressed conditions. Overall, the performance of the P-M model using the N-P bulk canopy resistance approach to simulate latent heat flux on half-hourly time intervals was better than that using the J-D approach during the maize growing season in the oases at the middle reaches of the Heihe River Basin, northwest China.

\section{Conclusions}

The present study indicates that the J-D and the N-P approaches can provide realistic estimations of bulk canopy resistance under well-watered and slightly stressed soil moisture conditions at a half-hourly time step during the maize growing season. However, the N-P approach seems to slightly underestimate the bulk canopy resistance, while the J-D approach tends to overestimate these values. Overall, the performance of the N-P approach was better than that of the $\mathrm{J}-\mathrm{D}$ approach in this study.

The P-M model simulation indicates that the P-M model using the J-D approach slightly underestimated the latent heat flux during the maize growing season. In contrast, the $\mathrm{P}-\mathrm{M}$ model using the N-P approach tended to overestimate the latent heat flux under dry soil conditions, and slightly underestimated the latent heat flux under wet soil conditions. The P-M model using the J-D and the N-P approaches both performed well in simulating the latent heat flux when compared to the measured values from the micrometeorological eddy covariance technique. The statistical evaluations of the present study indicate that the performance of the P-M model using the N-P approach is better at simulating the latent heat flux at half-hourly time steps during the maize growing season under relatively homogenous, non-drought stressed conditions.

Further refinements are necessary to make the P-M model using the bulk canopy resistance approach more applicable. Firstly, we should enhance the capacity of the field instrumentation to observe the variables in the P-M model and two bulk canopy resistance approaches with better accuracy. This would aid in optimizing the parameterization of both the J-D and the N-P bulk canopy resistance approaches, and could improve the performance of the P-M model in the simulation of ET of the cropped field in this study. For example, the canopy variables are difficult to obtain, particularly, the minimum leaf stomatal resistance, which is the most important parameter for the J-D and N-P approaches. Secondly, the aerodynamic resistance should be corrected for atmospheric stability to obtain better simulation of ET, following the approach proposed by Liu et al. (2007). Additionally, the simplicities of the P-M model affect its performance; such as the adequate fetch above canopy measurements, regarding canopy as a big leaf assumption. Further investigations and studies are needed to address some of these issues.

Acknowledgements. This research was supported by the National Natural Science Foundation of China (No. 40930634; 40801014), the Talent Training Program for Young Scientist in West China from the Chinese Academy of Sciences (No.828981001), the Major State Basic Research Development Program of China (973 Program) (No. 2009CB421302). The data used in the paper are provided by the CAS Action Plan for West Development Program (No. KZCX2-XB2-09) and Chinese State Key Basic Research Project (No. 2007CB714400).

Edited by: X. W. Li

\section{References}

Ács, F.: A coupled soil-vegetation scheme: description, parameters, validation, and sensitivity studies, J. Appl. Meteor., 33, 268-284, 1994.

Allen, R. G., Pruitt, W. O., Wright, J. L., Howell, T. A., Ventura, F., Snyder, R., Itenfisu, D., Steduto, P., Berengena, J., Yrisarry, J. B., Smith, M., Pereira, L. S., Raes, D, Perrier, A., Alves, I., Walter, I., and Elliott, R. : A recommendation on standardized surface resistance for hourly calculation of reference $\mathrm{ET}_{0}$ by the FAO56 Penman-Monteith method, Agr. Water Manag., 81, 1-22, 2006.

Baldocchi, D. and Meyers, T.: On using eco-physiological, micrometeorological and biogeochemical theory to evaluate carbon, dioxide, water vapor and trance gas fluxes over vegetation: a perspective, Agr. Forest Meteorol., 90, 1-25, 1998.

Ball, J. T., Woodrow, I. E., and Berry, J. A.: A model predicting stomatal conductance and its contribution to the control of photosynthesis under different environmental conditions, in: Progress in Photosynthesis Research: Proceedings of the Seventh International Congress on Photosynthesis, edited by: Biggins, J., Martinus-Nijhoff Publishers, Dordrecht, The Netherlands, 221224, 1987.

Brutsaert, W.: Evaporation into the Atmosphere: Theory, History, and Application, Kluwer, Boston, USA, 299 pp., 1982.

Collatz, G. J. J., Ball, J. T., Grivet, C., and Berry, J. A.: Physiological and environmental regulation of stomatal conductance, photosynthesis and transpiration: A model that includes a laminar boundary layer, Agr. Forest Meteorol., 92, 73-95, 1991.

Collatz, G. J. J., Ribas-Carbo, M., and Berry, J. A.: Coupled photosynthesis-stomatal conductance model for leaves of $\mathrm{C}_{4}$ plants, Aust. J. Plant. Physiol., 19, 519-538, 1992.

Falge, E., Baldocchi, D.D., Olson, R., Anthoni, P., Aubinet, M., Bernhofer, C., Burba, G., Ceulemans, R., Clement, R., and Dolman, H.: Gap filling strategies for long term energy flux data sets, Agr. Forest Meteorol., 107, 71-77, 2001.

Jacobs, C. M. J. and De Bruin, H. A. R. : Predicting regional transpiration at elevated atmospheric $\mathrm{CO}_{2}$ : influence of the PBLvegetation interaction, J. Appl. Meteorol. Clim., 36, 1663-1675, 1997. 
Jarvis, P. G.: The interpretation of the variations in leaf water potential and stomatal conductance found in canopies in the field, Philos. T. R. Soc. B., 273, 593-610, 1976.

Ji, X. B., Kang, E. S., Chen, R. S., Zhao, W. Z., Zhang, Z. H., and Jin, B. W.: The impact of the development of water resources on environmental in arid inland river basin of Hexi region, Northwestern China, Environ. Geol., 50, 793-801, 2006.

Ji, X. B., Kang, E. S., Chen, R. S., Zhao, W. Z., Zhang, Z. H., and Jin, B. W.: A mathematical model for simulating water balances in cropped field experiment under conventional flood irrigation in arid inland of Northwestern China, Agr. Water Manag., 87, 337-346, 2007.

Ji, X. B., Kang, E. S., Zhao, W. Z., Zhang, Z. H., and Jin, B.W.: Simulation of heat and water transfer in a surface irrigated, cropped sandy soil, Agr. Water Manage., 96, 1010-1020, 2009.

Jia, Y., Ding, X., Qin, C., and Wang, H.: Distributed modeling of landsurface water and energy budgets in the inland Heihe river basin of China, Hydrol. Earth Syst. Sci., 13, 1849-1866, doi:10.5194/hess-13-1849-2009, 2009.

Kaimal, J. C. and Finnigan, J. J.: Atmospheric Boundary Layer Flows: Their Structure and Measurement, Oxford University Press, New York, USA, 289 pp., 1994.

Kang, E. S., Lu, L., and Xu, Z. M.: Vegetation and carbon sequestration and their relation to water resources in an inland river basin of Northwest China. J. Environ. Manage., 85, 702-710, 2007.

Kite, G.: Using a basin-scale hydrological model to estimate crop transpiration and soil evaporation, J. Hydrol., 229, 59-69, 2000.

Kolle, O., and Rebmann, C.: Eddysoft - Documentation of a Software Package to Acquire and Process Eddy Covariance Data, Jena, Technical Reports - Max-Planck-Institut für Biogeochemie 10, 85-88, 2007.

Kristensen, L., Mann, J., Oncley, S. P., and Wyngaard, J. C.: How close is close enough when measuring scalar fluxes with displaced sensors, J. Atmos. Ocean. Tech., 14, 814-821, 1997.

Leuning, R.: A critical appraisal of a combined stomatalphotosynthesis model for C3 plants, Plant Cell Environ., 18, 339-355, 1995.

Lecina, S., Martínez-Cob, A., Pérez, P. J., Villalobos, F. J., and Baselga, J. J.: Fixed versus varialble bulk canopy resistance for referance evapotranspiration estimation using the Penman-Monteith equation under semiarid conditions, Agr. Water Manag., 60, 181-198, 2003.

Liu, Shaomin, Lu, L., Mao, D., and Jia, L.: Evaluating parameterizations of aerodynamic resistance to heat transfer using field measurements, Hydrol. Earth Syst. Sci., 11, 769-783, doi:10.5194/hess-11-769-2007, 2007.

Massman, W. J.: A simple method for estimating frequency response corrections for eddy covariance systems, Agr. Forest Meteorol., 104, 185-198, 2000.

McMillen, R. T.: An eddy correlation technique with extended applicability to non-simple terrain, Bound.- Lay. Meteorol., 43, 231-245, 1988.

Molina, J. M., Martínez, V., González-Real, M. M., and Baille, A.: A simulation model for predicting hourly pan evaporation from meteorological data, J. Hydrol., 318, 250-261, 2006.
Monteith, J. L.: Evaporation and environment, In: Proceedings of the 19th Symposium of the Society for Experimental Biology, Cambridge University Press, New York, 205-233 pp., 1965.

Monteith, J. L. and Unsworth, M. H.: Principles of Environmental Physics, Edward Arnold Press, London, 291 pp., 1990.

Niyogi, D. S., and Raman, S. : Comparison of four different stomatal resistance schemes using FIFE observations, J. Appl. Meteorol. Clim., 36, 903-917, 1997.

Noilhan, J. and Planton, S.: A simple parameterization of land surface processes for meteorological Models, Mon. Weather Rev., 117, 536-549, 1989.

Penman, H. L.: Natural evaporation from open water, bare soil and grass, Proceedings of the Royal Society (Series A) 193, 120-146, 1948.

Pereira, L. S., Perrier, A., Allen, R. G., ASCE, M., and Alves, I.: Evapotranspiration: concepts and future trends, J. Irrig. Drainage Eng-ASCE, 125, 45-51, 1999.

Prestley, C. H. B. and Taylor, R. J.: On the assessment of surface heat flux and evaporation using large-scale parameters, Mon. Weather Rev., 100, 81-92, 1972.

Rana, G., Katerji, N., and Mastrorilli, M.: Environmental and soilplant parameters for modeling actual crop evapotranspiration under water stress conditions, Ecol. Model., 101, 363-371, 1997.

Ronda, R. J., de Bruin, H. A. R., and Holtslag, A. A. M.: Representation of the canopy conductance in modeling the surface energy budget for low vegetation, J. Appl. Meteorol. Clim., 40, 1431-1444, 2001.

Schmugge, T. J. and André, J. C.: Land Surface Evaporation Measurement and Parameterization, Springer, New York, USA, 116 pp., 1991.

Sellers, P. J., Randall, D. A., Collatz, G. J., Berry, J. A., Field, C. B., Dazlich, D. A., Zhang, C., Collelo, G. D., and Bounoua, L.: A revised land surface parameterization (SiB2) for Atmospheric GCMs. Part I: model formulation, J. Climate, 9, 676-705, 1996.

Shuttleworth, W. J. and Wallace, J. S.: Evaporation from sparse crops - an energy combination theory, Q. J. Roy. Meteor. Soc., 111, 839-855, 1985.

Tattari, S., Ikonen, J. P., and Sucksdorff, Y.: A comparison of evapotranspiration above a barley field on quality tested Bowen ratio data and Deardorff modeling, J. Hydrol., 170, 1-14, 1995.

Vörösmarty, C. J., Federer, C. A., and Schloss, A. L.: Potential evaporation functions compared on US watersheds: Possible implications for global-scale water balance and terrestrial ecosystem modeling, J. Hydrol., 207, 147-169, 1998.

Webb, E. K., Pearman, G. I., and Leuning, R.: Correction of flux measurements for density effects due to heat and water vapor transfer, Q. J. Roy. Meteor. Soc., 106, 85-100, 1980.

Widmoser, P.: A discussion on and alternative to the PenmanMonteith equation, Agr. Water Manag., 96, 711-721, 2009.

Zhang, H. and Nobel, P. S.: Dependency of ci/ca and leaf transpiration efficiency on the vapour pressure deficit, Aust. J. Plant. Physiol., 23, 561-568, 1996. 